\title{
PARTISIPASI MASYARAKAT DALAM PEMBERDAYAAN LINGKUNGAN
}

\author{
Yasril Yazid $^{1)}$, Nur Alhidayatillah ${ }^{2)}$ \\ 1) 2) Dosen Fakultas Dakwah dan Komunikasi,UIN Suska Riau, \\ Jl. HR Soebrantas Km 15 Simpangbaru, Tampan, Pekanbaru 50275 \\ Email: nuralhidayatillah@uin-suska.ac.id
}

\begin{abstract}
Abstrak
Partisipasi masyarakat harus ada dalam semua hal, termasuk dalam memelihara kebersihan lingkungan. Lingkungan yang bersih akan mencerminkan kondisi orang-orang yang tinggal di dalamnya. Pemberdayaan lingkungan merupakan cita-cita bersama sehingga juga harus diciptakan secara bersama-sama pula. Berdayanya lingkungan ditandai dengan kondisi lingkungan yang mendukung aktivitas masyarakatnya, artianya aktivitas masyarakat tidak akan terganggu dikarenakan alasan lingkungannya. Misalnya, dikarenakan lingkungan yang kotor menyebabkan gangguan kesehatan sehingga menghalangi aktivitas masyarakat. Pencemaran lingkungan dan segala permasalahannya dapat diatasi jika semua komponen yang ada mau peduli dan bertanggung jawab. Melalui partisipasi aktif, masyarakat diharapkan mau terlibat secara langsung sehingga akan memberikan kontribusi yang nyata sehingga memberikan pengaruh yang besar. Partisipasi masyarakat dalam menciptakan lingkungan yang berdaya tidak akan terjadi jika partisipasi aktif tidak terbentuk. Partisipasi masyarakat bisa dimulai dari kepedulian masyarakat terhadap informasi-informasi lingkungan, baik manfaat maupun dampak. Kemudian informasi yang ada semakin diperkuat sehingga menjadi sebuah pengetahuan tentang lingkungan. Selanjutnya, lingkungan bisa direkayasa sesuai dengan keinginan masyarakat sehingga bisa menjadi pendukung dalam setiap aktivitasnya.
\end{abstract}

Kata kunci: partisipasi, pemberdayaan, lingkungan

\section{Pendahuluan}

Masyarakat berpengaruh terhadap kondisi lingkungan. Kondisi lingkungan akan menggambarkan keadaan orang-orang yang berada di dalamnya. Sebuah lingkungan mempunyai beragam komponen yang saling berkaitan, baik secara langsung maupun tidak langsung. Keterkaitan ini, harus mempunyai sinergi agar semuanya bisa berjalan selaras sesuai dengan fungsinya masing-masing. Terkait dengan permasalahan lingkungan yang ada maka salah satu cara dalam menanggulanginya dilakukan dengan menggunakan pendekatan partisipasi masyarakat. Partisipasi masyarakat merupakan keterlibatan mental dan emosi orang-orang untuk menyumbangkan ide-ide dalam proses pembangunan (Davis:1977, Mubyarto:1970). Keterlibatan secara mental dan emosi muncul dalam bentuk kepedulian, rasa memiliki, aksi nyata, dan perilaku yang mendukung untuk membersihkan lingkungan. Individu yang mau terlibat dalam menjaga kondisi lingkungan akan membuat kegiatan dan terobosan-terobosan baru untuk menjaga lingkungan.

Partisipasi dianggap sebagai sesuatu yang penting sehingga menjadi alasan orang lain untuk melakukan sebuah perbuatan. Setiap 
perbutan akan mempunyai konsekuensi yang berdampak terhadap kondisi yang ada di sekitarnya. Jadi partisipasi masyararakat merupakan keterlibatan setiap individu untuk menciptakan sebuah kondisi yang nyata terlihat di lingkungannya. Masyarakat sebagai bagian dari sebuah ekosistem akan memberi pengaruh terhadap lingkungannya, baik secara langsung maupun tidak langsung. Masyarakat yang mendiami sebuah wilayah akan selalu melihat, menilai, merekayasa, ataupun menciptakan kondisi yang sesuai dengan yang diinginkannya. Senada dengan yang dikatakan oleh Isbandi (2007: 7) partisipasi masyarakat adalah keikutsertaan masyarakat dalam proses pengidentifikasian masalah dan potensi yang ada dalam masyarakat, pemilihan dan pengambilan keputusan tentang alternatif solusi untuk menangani masalah, pelaksanaan upaya mengatasi masalah, dan keterlibatan masyarakat dalam proses mengevaluasi permasalahan yang terjadi. Pernyataan Isbandi ini bisa dijadikan alasan mengapa masyarakat yang harus diikutsertakan dalam upaya pemeliharaan lingkungan.

Masyarakat merupakan orang-orang yang mendiami sebuah wilayah, melahirkan kebudayaan dan peraturan yang disepakati di sebuah wilayah.Misalnya, lingkungan yang rapi menandakan masyarakatnya aktif melakukan pemeliharaan terhadap lingkungannya. Misalnya melalui kegiatan gorong-royong yang dilakukan secara bersama-sama.Pencemaran lingkungan yang terjadi saat ini berkenaan dengan cara pemahaman atau cara pandang manusia terhadap dirinya, alam, dan tempat manusia dalam keseluruhan ekosistem. Kesalahan dalam memahami ini menyebabkan kesalahan pola perilaku manusia.

Berbagai kegiatan yang dilakukan manusia menyebabkan pencemaran atau kerusakan lingkungan. Pencemaran sungai, sumber mata air, udara, tanah, dan sebagainya terjadi di mana-mana. Salah satu contohnya terjadi di aliran sungai Citarum Kecamatan Kertasari Kabupaten Bandung, alirannya dicemari pupuk kimia dan kotoran sapi yang mengotori aliran air ketika hujan. Kondisi ini, bisa menjadi gambaran secara umum kondisikondisi sungai yang ada di Indonesia, walaupun terdapat perbedaan-perbedaan. ${ }^{1}$

Contoh di atas merupakan salah satu gambaran kondisi sungai di Indonesia. Tidak dapat dipungkiru, hampir semua kota di Indonesia mempunyai masalah terkait dengan pencemaran sungai, tanah, dan udara, sehingga turut mempengaruh kondisi masyarakat dan lingkungan yang langsung terkena imbasnya. Aktivitas produksi dan perilaku konsumtif manusia melahirkan sikap dan perilaku eksploitatif. Menilai sesuatu berdasarkan nilainya, mencari keuntungan sebesar-besarnya. Tidak peduli cara yang digunakan, betul atau salah tidak menjadi masalah. Selain itu paham materialisme, kapitalisme, dan pragmatisme dengan kemajuan sains dan teknologi ikut mempercepat dan memperburuk kerusakan lingkungan.

Seharusnya, pemahaman individu terhadap lingkungan harus dirubah. Pemahaman terhadap kondisi lingkungan harus ditingkatkan. Lingkungan akan baik, jika pemahaman masyarakat sudah betul. Selanjutnya, tulisan ini akan memaparkan bagaimana partisipasi masyarakat bisa menciptakan lingkungan yang kondusif dan menyokong kehidupan manusia. Walaupun hanya disajikan dalam bentuk konseptual, semoga tulisan ini, bisa mewakili ide terkait peran partisipasi masyarakat dalam pemberdayaan lingkungan.

\section{Bentuk-bentuk partisipasi}

Partisipasi masyarakat termasuk salah satu nilai yang dijunjung tinggi di Indonesia. Kerjasama, musyawarah, dan gotong royong merupakan bagaian dari partisipasi. Nilai-nilai yang dikandungnya bisa dijadikan sebagai acuan dalam mengekspresikannya. Oleh karena itu, ia mempunyai peran penting dalam

\footnotetext{
${ }^{1}$ Kompas.com, Menteri LH, 75 Persen Sungai di Indnesia Tecemar Berat, 24 maret 2014, 11.30 WIB
} 
menciptakan kondisi lingkungan. Lingkunganpun bisa dijaga atau dikembalikan fungsinya melalui partisipasi masyarakat.

Sampai saat ini, penyelamatan lingkungan telah banyak dilakukan baik melalui penyadaran masyarakat dan pemangku kepentingan (stakeholders), upaya pembuatan peraturan, kesepakatan nasional dan internasional, undang-undang, maupun melalui penegakan hukum. Penyelamatan melalui pemanfaatan sains dan teknologi serta programprogram teknis lain juga banyak dilakukan. Tetapi dari banyaknya kegiatan yang dilakukan masih belum bisa mengatasi masalah lingkungan. Supaya masalah yang berkenaan dengan lingkungan tidak semakin parah maka perlu diadakan penyadaran masyarakat agar mau berperan aktif dalam menjaga lingkungannya.

Holil Sulaiman mengatakan ada beberapa bentuk partisipasi yang dapat diberikan masyarakat dalam pembangunan yaitu partisipasi uang, partisipasi harta benda, partisipasi tenaga, partisipasi keterampilan, partisipasi buah pikiran, partisipasi sosial, partisipasi dalam proses pengambilan keputusan dan partisipasi refresentatif. ${ }^{2}$ Selanjutnya Sulaiman membagi bentuk partisipasi ke dalam lima macam, yaitu: Pertama, partisipasi langsung dalam kegiatan bersama secara fisik dan tatap muka. Kedua, partisipasi dalam bentuk iuran. Ketiga, partisipasi dalam bentuk dukungan. Keempat, partisipasi dalam proses pengambilan keputusan. Kelima, partisipasi representatif dengan memberikan kepercayaan dan mandat kepada wakil yang duduk dalam organisasi atau panitia. $^{3}$

Menurut Sundari Ningrum, (Sugiyah, 2010:38) ia mengklasifikasikan partisipasi menjadi dua berdasarkan cara keterlibatannya, yaitu: (1) Partisipasi langsung, yaitu: partisipasi yang terjadi apabila individu menampilkan

\footnotetext{
${ }^{2}$ Holil Sulaiman, Partisipasi Sosial dalam Usaha Kesejahtaraan Sosial(Bandung: 1980), h. 81

${ }^{3}$ Abu huraerah, op.cit., h. 117
}

kegiatan tertentu dalam proses partisipasi. Partisipasi ini terjadi apabila setiap orang dapat mengajukan pandangan, membahas pokok permasalahan, mengajukan keberatan terhadap keinginan orang lain atau terhadap ucapannya. (2) Partisipasi tidak langsung, yaitu partisipasi yang terjadi apabila individu mendelegasikan hak partisipasinya pada orang lain.

Selain dua pendapat di atas Cohen dan Uphoff (Siti Irene A.D., 2011:61) membedakan partisipasi lebih rinci, partisipasi dibagi menjadi empat jenis yaitu partisipasi dalam pengambilan keputusan, partisipasi dalam pelaksanaan, partisipasi dalam pengambilan manfaat dan partisipasidalam evaluasi. Pertama, partisipasi dalam pengambilan keputusan. Partisipasi ini berkaitan dengan penentuan alternatif dengan masyarakat yang berhubungan dengan gagasan atau ide yang menyangkut kepentingan bersama. Wujud dari partisipasi masyarakat yaitu keterlibatan masyarakat untuk menentukan arah dan orientasi pembangunan. Contoh dari partisipasi ini antara lain seperti kehadiran rapat, diskusi, sumbangan pemikiran, tanggapan atau penolakan terhadap program yang ditawarkan. Kedua, partisipasi dalam pelaksanaan suatu program meliputi: menggerakkan sumber daya, dana, kegiatan administrasi, koordinasi dan penjabaran program. Ketiga, partisipasi dalam pengambilan manfaat. Partisipasi tidak lepas dari hasil pelaksanaan program yang telah dicapai baik yang berkaitan dengan kuantitas maupun kualitas. Dari segi kualitas, dapat dilihat dari peningkatan output, sedangkan dari segi kuantitas dapat dilihat seberapa besar presentase keberhasilan program. Keempat, partisipasi dalam evaluasi. Partisipasi masyarakat dalamevaluasi ini berkaitan dengan masalah pelaksanaan program secara menyeluruh. Partisipasi ini bertujuan untuk mengetahui ketercapaian program yang telah direncanakan sebelumnya.

Jadi, partisipasi bisa dikelompokkan menjadi beberapa bentuk sesuai dengan konteksnya, yaitu bentuk partisipasi dalam 
bentuk nyata (memiliki wujud) dan bentuk partisipasi dalam bentuk tidak nyata (abstrak). Bentuk partisipasi nyata misalnya uang, harta benda, tenaga dan keterampilan. Sedangkan partisipasi yang tidak nyata adalah partisipasi buah pikiran, partisipasi sosial, pengambilan keputusan dan partisipasi evalusai dalam sebuah program. Partisipai masyarakat harus terus dilakukan karena beragam masalah akan terus terjadi dan semakin meningkat setiap tahunnya. Pengelompokan partisipasi terjadi karena memperlihatkan berbagai kemungkinankemungkinan yang bisa menunjukkan seseorang berpartisipasi. Berpartisipasi tidak terbatas pada uang atau materi saja tetapi bentuk dukungan moril juga wujud dari partisipasi. Luasnya cakupan partisipasi akan memperkaya wujud partisipasi itu sendiri.

\section{Pentingnya Partisipasi Masyarakat dalam Memelihara Lingkungan}

Permasalahan lingkungan semakin hari semakin parah. Salah satu faktor yang mempengaruhinya yaitu jumlah penduduk yang sangat padat. Kepadatan penduduk menghasilkan limbah atau sampah yang sangat besar. Apabila limbah atau sampah ini tidak bisa dikelola dengan baik maka kerusakan lingkungan tidak bisa dihindari. Oleh karena itu diperlukan adanya kesadaran penduduk terhadap masalah-masalah lingkungan yang ada. Baik masalah lingkungan di perkotaan, di pedesaan, daerah konfik, daerah rawan bencana, dan sebaginya.

Permasalahan lingkungan yang terjadi di perkotaan Indonesia, secara umum meliputi tiga hal pokok, yaitu: Pertama, kualitas lingkungan hidup yang cenderung menurun, masalah kebersihan (sampah), ruang terbuka hijau (RTH), serta pencemaran air dan udara. Kedua, kapasitas aparatur pemerintah yang relatif kurang memadai dari masalah yang dihadapi. Ketiga, partisipasi atau peran serta masyarakat dalam pengelolaan lingkungan perkotaan relatif masih rendah. ${ }^{4}$

Permasalahan lingkungan yang terjadi di perkotaan mencerminkan kepedulian masyarakat yang rendah untuk menjaga lingkungan. Lingkungan yang menyimpan berbagai potensi akan rusak akibat ulah tangan manusia yang tidak peduli dengan kondisi yang ada di sekitarnya. Kerusakan alam akan berakibat fatal bagi keberlangsungan makhluk hidup. Baik secara langsung atau tidak langsung dampak dari pengrusakan alam akan dirasakan oleh segala komponen yang tinggal di daamnya. Alam dan segala potensinya akan terjamin keberadaannya apabila masyarakat mau berpartisipasi menjaganya. Masyarakat mempunyai hak dan kewajiban yang sama dalam pengelolaan lingkungan berdasarkan UU No. 23 pasal 5 Tahun 1997 yang menyatakatan:

“(1) Setiap orang mempunyai hak yang sama atas lingkungan hidup yang baik dan sehat. (2) Setiap orang mempunyai hak atas informasi lingkungan hidup yang berkaitan dengan peran dalam pengelolaan lingkungan hidup. (3) Setiap orang mempunyai hak untuk berperan dalam rangka pengelolaan lingkungan hidup sesuai dengan peraturan perundang-undangan yang berlaku."

UU No. 23 pasal 5 menjelaskan hak atas lingkungan yang baik, hak memperoleh informasi, dan hak untuk mengelola lingkungan hidup sesuai dengan ketentuan yang berlaku. Oleh karena itu, semua masyarakat harus mau terlibat secara langsung dalam menjaga lingkungan atau dikenal dengan istilah berpartisipasi. Partisipasi diartikan sebagai bentuk interaksi sosial dari suatu kegiatan. ${ }^{5}$ Partisipasi masyarakat akan sangat efektif

${ }^{4}$ Kementerian Lingkungan Hidup,Siaran PresRapat Koordinasi Nasional Program Adipura. 07 Oktober 2012

${ }^{5}$ Aca Sughandhy, dkk. Pembangunan Berkelanjutan Berwawasan Lingkungan (Jakarta: Bumi Aksara, 2007), h. 108 
apabila masyarakat aktif dalam mengontrol pengelolaan lingkungan yang ada di sekitarnya. Dalam rangka pengelolaan lingkungan hidup tentunya tidak akan terlepas dari peran aktif masyarakat. Setiap orang mempunyai hak yang sama atas kondisi lingkungan hidup yang layak dan baik.

Lingkungan akan senantiasa mempengaruhi orang-orang yang tinggal di sekitarnya. Lingkungan juga memiliki peran penting bagi idividu atau masyarakat, pengaruh lingkungan bagi orang yang tinggal di dalamnya sebagai berikut: (1) Alat untuk kepentingan dan kelangsungan hidup individu dan menjadi alat pergaulan sosial. (2) Tantangan bagi individu, dan individu akan berupaya untuk menundukkannya. (3) Sesuatu yang diikuti individu, maksudnya lingkungan yang beragam memberi rangsangan kepada individu untuk berpartisipasi dan ditiru apabila dianggap sesuai dengan dirinya. (4) Obyek penyesuaian diri bagi individu, bisa secara memanipulasi atau mengubah lingkungannya. ${ }^{6}$

Partisipasi masyarakat juga berfungsi sebagai pengontrol kebijakan pemerintah. Dalam artian masyarakat ikut mengawal (peduli) terhadap kebijakan yang diambil pemerintah sehingga pemerintah tidak bertindak sendiri dalam mengatur tata ruang kota, pembangunan gedung-gedung, pembangunan tempat-tempat umum, ruang terbuka dan sebagainya. Masyarakat mempunyai hak untuk mengawasi setiap kebijakan dan kegiatan yang dilakukan pemerintah berkaitan dengan lingkungan. Apabila tidak ada pengawasan dari masyarakat dikhawatirkan akan terjadi ketidakadilan pemerintah dalam membuat kebijakan dan pelaksanaan kegiatan yang tidak sesuai dengan prosedur yang ada. Masyarakat seringkali menjadi korban pembangunan atau kegiatan yang dilakukan tanpa melibatkan masyarakat di dalamnya.

\footnotetext{
${ }^{6}$ Rusmin Tumanggor,et al, Ilmu Sosial \& Budaya Dasar, (Jakarta: Kencana, 2010), h. 163
}

Masyarakat aktif, yang mau bergerak dalam menjaga kelestarian lingkungan tidak mudah diciptakan. Semua ini memerlukan pengertian, kesadaran, dan penghayatan oleh masyarakat terhadap masalah-masalah yang dialami sebagai dampak dari lingkungan yang kotor serta upaya pemecahannya. Oleh karena itu, untuk menjaga kelestarian lingkungan perlu diadakan pengorganisasian masyarakat. Pengorganisasian masyarakat dilakukan untuk mengkoordinir masyarakat agar menjaga lingkungan secara aktif dan kondusif. Pengorganisasian masyarakat akan membentuk masyarakat yang aktif, mampu mengenali dan memecahkan masalah yang ada di sekitarnya.

Pengorganisasian masyarakat pada hakikatnya adalah menumbuhkan, membina dan mengembangkan partisipasi masyarakat dibidang pembangunan mental dan mau berperan dalam menjaga kebersihan lingkungan disekitar mereka. Lingkungan dengan aneka ragam kekayaannya merupakan sumber inspirasi dan daya cipta untuk diolah menjadi kekayaan budaya bagi individu. Kekayaan lingkungan bisa mempengaruhi seseorang karena manusia hidup adalah manusia yang berfikir dan serba ingin tahu serta mencobacoba terhadap segala yang tersedia di alam sekitarnya. ${ }^{7}$ Alam akan merangsang manusia untuk terus berkreasi dan berinovasi sehingga bisa memanfaatkan sumber daya yang ada. Manusia yang aktif akan menjadikannya sebagai pribadi yang tangguh dan mampu memenuhi segala kebutuhannya.

\section{Konsep Islam tentang Kebersihan Lingkungan}

Islam

adalah

agama

Rahmatallil'alamin (QS 21:107) yang memberi keberkahan kepada seluruh alam. Islam juga mengatur segala aspek kehidupan manusia termasuk masalah kebersihan lingkungan. Beberapa ayat Alqur'an menjelaskan bahwa Allah SWT menciptakan alam semesta beserta isinya dengan pertimbangan yang matang,

\footnotetext{
${ }^{7}$ Rusmin Tumanggor, op.cit.,h. 163-164
} 
seimbang, dan setiap ciptaanNya tersebut mempunyai manfaat dan fungsi (surat 6:38, surat $16: 66,67,68$, dan 69 ; surat $25: 2$, surat 54:49, surat 80:24 s/d 32). Selanjutnya, Allah SWT juga menyatakan bahwa manusia adalah ciptaaanNya yang unik dan menjadikannya sebagai khalifah di bumi (surat 6: 165, surat 7: 69,129 , surat 10: 14 , surat $24: 55$, surat $38: 26$ ).

Islam menjadi pelopor dalam pengelolaan lingkungan sebagai manifestasi dari rasa kasih bagi alam semesta. Nabi Muhammad SAW juga melarang manusia untuk membuang air seni ke dalam sumber mata air, jalanan, di tempat teduh, dan di dalam liang (tempat hidup) binatang. Selain melarang membuat kerusakan di muka bumi, Islam juga mempunyai kewajiban untuk menjaga kebersihan lingkungan. Hal ini dapat dilihat dari hadits Nabi tentang kebersihan sebagai berikut:

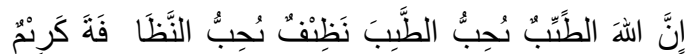

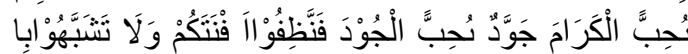

$$
\begin{aligned}
& \text { لَنَهُوْدِ }
\end{aligned}
$$

Artinya:"Bahwasanya Allah itu baik, menyukai kebaikan. Bahwasanya Allah itu bersih, menyukai kebersihan. Bahwasanya Allah itu sangat murah pemberiannya, menyukai kemurahan. Oleh karena itu bersihkanlah halaman-halaman rumahmu. Dan janganlah kamu menyerupai orangorang Yahudi". (H.R. Turmidzi). ${ }^{8}$

Hadits di atas menjelaskan bahwa manusia diperintahkan untuk selalu menjaga perilaku dan kebersihan. Kebersihan merupakan cerminan dari Islam. Baik kebersihan diri maupun lingkungan. Islam selalu menganjurkan umatnya untuk saling manjaga, saling melindungi, saling menghormati dan bersikap baik terhadap semua makhluk hidup.

${ }^{8}$ Muhammad Al Ghazali, Akhlak Seorang Muslim. (Semarang: Wicaksana, 1992), h. 313-314
Lingkungan dengan aneka ragam kekayaannya merupakan sumber inspirasi dan daya cipta untuk diolah menjadi kekayaan budaya bagi individu. Kekayaan lingkungan bisa mempengaruhi seseorang karena manusia hidup adalah manusia yang berfikir dan serba ingin tahu serta mencoba-coba terhadap segala yang tersedia di alam sekitarnya. ${ }^{9}$ Alam akan merangsang manusia untuk terus berkreasi dan berinovasi sehingga bisa memanfaatkan sumber daya yang ada. Manusia yang aktif akan menjadikannya sebagai pribadi yang tangguh dan mampu memenuhi segala kebutuhannya.

Islam memandang kebersihan sebagai hal yang sangat penting sehingga Rasulullah SAW bersabda:

$$
\text { النطا فة من الا يمان }
$$

Artinya : kebersihan itu adalah separuh dari iman (HR. Muslim)

Kebersihan dianggap sebagai cerminan keimanan seseorang karena kebersihan merupakan wujud dari pengamalan agama yang mantap. Islam mengajarkan prinsip-prinsip kesehatan, kebersihan dan kesucian lahir dan batin. Antara kesehatan jasmani dengan kesehatan rohani merupakan kesatuan sistem yang terpadu, sebab kesehatan jasmani dan rohani menjadi syarat bagi tercapainya suatu kehidupan yang sejahtera di dunia dan kebahagiaan di akhirat.

Sistem kebersihanan dalam Islam tercermin dalam ajaran syariat yang mewajibkan perbuatan membersihkan diri dari kotoran (najis), dari hadats dan dari kotoran hati. Semua itu berada dalam satu paket ibadah seperti wudhu', mandi, shalat dan lain sebagainya. Islam memandang kebersihan sebagai suatu hal yang sangat penting. Kebersihan fisik dan non fisik sama-sama diperhatikan agar pribadi muslim menjadi pribadi yang kuat, menjaga, dicintai, dan mencintai sesamanya.

\footnotetext{
${ }^{9}$ Rusmin Tumanggor, op.cit., h. 163-164
} 
Umat Islam selalu diajarkan untuk menjaga kebersihan baik secara zhahir ataupun batin. Para ulama juga menempatkan kajian Islam tentang kebersihan di awal buku mereka yang biasanya dikenal dengan Bab Thaharah. Graham Perkes dari University Hawai yang menekuni peran agama dalam mengamati krisis budaya masa kini, memfokuskan penelitiannya tentang hubungan kebudayaan manusia dengan alam lingkungannya. Ia menyatakan bahwa pandangan agama suatu kelompok masyarakat sangat mempengaruhi dalam menentukan sikap dan perilaku terhadap alam dan lingkungannya. ${ }^{10} \mathrm{Hal}$ ini menunjukkan bahwa Islam merupakan agama yang sangat perduli terhadap kebersihan. Islam telah mengajarkan umatnya untuk hidup bersih, mencintai, dan menjaga lingkungan. Apabila umat Islam mampu mewujudkannya maka masalah lingkungan yang berkaitan dengan pencemaran, masalah sampah, dan lainnya akan mampu diatasi dengan mudah karena ajaran kebersihan yang ada dalam Islam telah melekat dalam diri setiap pemeluknya.

Kesadaran masyarakat terhadap
kebersihan akan meringankan beban pemerintah. Pemerintah tidak perlu lagi membuat undang-undang atau peraturan yang berkaitan dengan lingkungan. Masyarakat dan pemerintah harus selalu bekerjasama untuk menjaga kebersihan lingkungan dan segala komponen yang ada di dalamnya. Lingkungan yang sehat akan membawa dampak positif bagi semua orang.

\section{Upaya Pemeliharaan Lingkungan}

Upaya pemeliharaan lingkungan membutuhkan partisipasi dari berbagai pihak seperti pemerintah, media massa, pendidik, tokoh-tokoh masyarakat, dan masyarakat umum. Beberapa aspek dasar yang diperlukan dalam memlihara lingkungan sebagai berikut:

10 Alwi Shihab, Islam Inklusif Menuju Sikap Terbuka Dalam Beragama Cetakan IV (Bandung: Mizan. 1999), h. 158
1. Pendidikan lingkungan: pendidikan lingkungan memiliki peran yang strategis dan penting dalam mempersiapkan manusia untuk memecahkan masalah-masalah lingkungan. Melalui pendidikan lingkungan orang dapat mengembangkan pemikiran dan teknologi yang mampu mendukung langkah yang tepat untuk skala lokal maupun global. Selain itu, pendidikan merupakan jalur positif untuk menuju perubahan pemahaman mengenai lingkungan hidup. Diharapkan semakin tinggi tingkat pendidikan masyarakat maka semakin tinggi pula persepsi dan kepedulian masyarakat terhadap lingkungan.Pendidikan lingkungan bisa diterapkan sejak Tingkat Kanak-Kanak (TK) hingga perguruan tinggi. Pendidikan lingkungan bisa juga diadakan melalui Lembaga Swadaya Masyarakat (LSM) dan pemerintah. Intinya semua kalangan bisa melakukan pendidikan lingkungan, sesuai dengan kemampuan dan keadaan di sekitarnya.

2. Peningkatan partisipasi masyarakat: partisipasi masyarakat menjadi penentu keberhasilan dalam menjaga kelestarian lingkungan. Penjaga sekaligus perusak lingkungan adalah manusia itu sendiri. Oleh karena itu kesadaran masyarakat untuk menjaga lingkungan harus ditanamkan terlebuh dahulu. Apabila kesadaran telah ada maka dengan sendirinya rasa peduli akan muncul dan rasa tanggung jawab untuk menjaga lingkungan akan ada. Jika kesadaran masyarakat telah ada maka pemerintah tidak akan kesulitan untuk menangani permasalahan lingkungan. Begitu juga masyarakat, tidak akan mendapati lingkungan yang rusak sehingga akan ada kenyamanan bagi semua yang tinggal di dalamnya.

3. Pemanfaatan media massa: pengetahuan manusia tentang lingkungan hidup harus disertai upaya penyebarluasan informasi ilmu pengetahuan agar tercipta lingkungan yang berkualitas. Peranan media massa 
dalam perluasan informasi tersebut sangat besar karena saat ini media komunikasi dan informasi menjadi kebutuhan semua kalangan. Oleh karena itu, media komunikasi dan informasi harus digunakan untuk menyebarkan kondisi lingkungan secara fakta dan menawarkan solusi untuk mengatasinyaa.

4. Kebijakan dan penegakan hukum lingkungan: penegakan hukum khususnya yang berkaitan dengan pelaksanaan kebijakan yang telah dibuat dan perlindungan lingkungan merupakan faktor yang sangat menentukan dalam pengelolaan lingkungan. Walaupun berbagai kebijaksanaan telah diciptakankan dalam rangka untuk memperoleh lingkungan yang bersih dan berkualitas, masih banyak kegiatan perusakan lingkungan yang sengaja atau tidak dilakukan masyarakat.

Program-program seperti kali bersih, langit biru, analisis dampak lingkungan, penghargaan Kalpataru, Piala Adipura, dan lainnya lebih terkesan sebagai semboyan atau lambang program yang dilaksanakan dengan baik. Program ini, lebih bersifat musiman, bahkan ada yang hanya menjadi target kepala daerah untuk mendapat penghargaan sebagai prestise selama masa jabatannya. Kesannya program-program tersebut tidak mencapai target sasaran.

5. Kebijakan dan penegakan hukum lingkungan secara Islam: Islam menegaskan bahwa setiap individu akan dimintai pertanggung jawaban perilakunya terhadap alam, lingkungan, dan makhluk hidup lainnya. Setiap individu muslim berkewajiban untuk berlaku baik dan dapat dimanifestasikan dengan jalan menjaga dan merawat lingkungan yang mampu mendukung kehidupan semua makhluk hidup. Islam tidak melarang pemanfaatan lingkungan demi kesejahteraan manusia, namun Islam mewajibkan dalam pemanfaatan tersebut harus dihindari pemanfaatan yang berlebihan.

\begin{abstract}
Islam selalu mengajarkan keseimbangan dalam semua hal termasuk dalam pemanfaatan lingkungan. Pemanfaatan yang berlebihan dapat mengakibatkan kerusakan lingkungan dan membahayakan makhluk hidup yang lain termasuk manusia sendiri. Islam menyarankan untuk melakukan pemanfaatan yang berkelanjutan (sustainable utilization) yang akan mampu memberikan kesejahteraan yang merata dan berkelanjutan bagi manusia dan mahkluk hidup lainnya.
\end{abstract}

\section{Penutup}

Pengelolaan lingkungan hidup tentunya tidak akan terlepas dari peran aktif masyarakat. Setiap orang mempunyai hak yang sama atas kondisi lingkungan hidup yang layak dan baik. Islam telah mengajarkan umatnya untuk hidup bersih, mencintai, dan menjaga lingkungan. Apabila umat Islam mampu mewujudkannya maka masalah lingkungan akan mampu diatasi dengan mudah karena ajaran kebersihan yang ada dalam Islam telah melekat dalam diri setiap pemeluknya. Partisipasi masyarakat akan sangat efektif ketika masyarakat aktif dalam mengontrol pengelolaan lingkungan yang ada di sekitarnya.

Upaya pemeliharaan lingkungan membutuhkan partisipasi dari berbagai pihak seperti pemerintah, media massa, pendidik, tokoh-tokoh masyarakat, dan masyarakat umum. Beberapa aspek dasar yang diperlukan dalam memelihara lingkungan yaitu: pendidikan lingkungan, peningkatan partisipasi masyarakat, pemanfaatan media massa, kebijakan dan penegakan hukum lingkungan, dan kebijakan dan penegakan hukum lingkungan secara Islami. Keberhasilan dalam menjaga kelestarian lingkungan akan membawa dampak yang positif bagi setiap komponen yang ada di dalamnya. Lingkungan yang sehat akan memberikan manfaat yang luar biasa. 


\section{DAFTAR KEPUSTAKAAN}

Abu Huraerah, Pengorganisasian dan Pengembangan Masyarakat Model dan Strategi Pembangunan Berbasis Kerakyatan, Cet. 2, Bandung: Humaniora, 2011.

Aca Sughandhy, et al,Pembangunan Berkelanjutan Berwawasan Lingkungan Jakarta : Bumi Aksara, 2007.

Aprilia Thenesa, et al, Pembangunan Berbasis Masyarakat, Bandung: Alfabeta, 2014.

Alwi Shihab, Islam Inklusif Menuju Sikap Terbuka Dalam Beragama, Cetakan IV, Bandung: Mizan.1999.

Holil Sulaiman, Partisipasi Sosial dalam Usaha Kesejahtaraan Sosial Bandung: 1980.

Isbandi Rukminto Adi, Perencanaan Partisipatoris Berbasis Asset Komunitas: Dari Pemikiran Menuju Penerapan. Depok: Fisip Ui Pres, 2007.

Rosmita,et al,Ilmu Kesejahteraan Sosial,Pekanbaru: Percetakan Pustaka Riau, 2011.

Muhammad Al Ghazali, Akhlak Seorang Muslim. Semarang: Wicaksana, 1992.

Rusmin Tumanggor,et al, Ilmu Sosial \& Budaya Dasar, Jakarta: Kencana, 2010.

Siahaan,Hukum Lingkungan dan Ekologi Pembangunan Edisi Kedua, Jakarta: Erlangga, 2004.

Salmadanis, Standar Kompetensi Pelaku Dakwah, Sumatra Barat: Imam Bonjol Pres, 2014.

Totok Murdikanto, et al, Pemberdayaan Masyarakat dalam Perspektif Kebijakan Publik, Bandung: Alfabeta, 2013.

Http://Kompas.com, Menteri LH, 75 Persen Sungai di Indnesia Tecemar Berat, 24 maret 2014, 11.30 WIB

Http://Kementerian Lingkungan Hidup,Siaran PresRapat Koordinasi Nasional Program Adipura. 07 Oktober 2012

Http://Ricky Darco, Kesehatan Lingkungan Menurut Pandangan Islam, htm, 07 November 2012.
Http://Muhammad Saidul Hudari, Islam \& Hubungannya dengan Kesehatan Lingkungan,Rabu, 05 Juni 2013. 